Communication

[Comunicação]

\title{
Meningoencephalitis caused by Bovine alphaherpesvirus 5 in Pernambuco, Brazil
}

[Meningoencefalite causada pelo Bovine alphaherpesvirus 5 em Pernambuco, Brasil]

B. Pajeú e Silva ${ }^{1}$, R.P.B. Melo' ${ }^{1}$, A.Q. Andrade Neto ${ }^{2}$, J.F.P. Cajueiro ${ }^{2}$, R.C Alves ${ }^{3}$, A.F.M. Dantas ${ }^{3}$, J.A.B. Afonso ${ }^{2}$, J.W. Pinheiro Junior ${ }^{1}$

${ }^{1}$ Universidade Federal Rural de Pernambuco - UFRPE - Recife, PE

${ }^{2}$ Clínica de Bovinos de Garanhuns - Universidade Federal Rural de Pernambuco - UFRPE - Garanhuns, PE ${ }^{3}$ Centro de Saúde e Tecnologia Rural - Universidade Federal de Campina Grande - Patos, PB

Bovine alphaherpesvirus 5 (BoHV5) is responsible for triggering a typical neurological condition, which has a high mortality rate in cattle up to 8 years of age (Barros et al., 2006; Rissi et al., 2006). The most important characteristic of BoHV5 lies in its ability to establish latency in the trigeminal ganglion, allowing the virus to perpetuate itself in the animal organism for a lifetime, being reactivated in periods of decreased immunity (Perez et al., 2002).

The main clinical signs associated with the infection caused by this agent include deep prostration, pressure of the head against objects, runny nostrils, involuntary movements, nystagmus, opisthotonus, and staggering, culminating in death between 4 and 10 days (Rissi et al., 2006).

BoHV5 has a worldwide distribution, but its occurrence is geographically limited to South America, mainly to Brazil and Argentina (Perez et al., 2002). Although its occurrence is described in Brazil, where it is considered one of the three main causative agents of neurological diseases in cattle (Queiroz et al., 2018; Terra et al., 2018), studies about its occurrence in the Northeast region are lacking, despite evidence of its presence (Galiza et al., 2010). The objective of this study was to report the occurrence of BoHV5 in cattle with neurological signs in the period from 2012 to 2016 in the state of Pernambuco.

Samples of the central nervous system (cerebellum, pituitary, rete mirabile, brain stem, telencephalon, medulla, and thalamus) embedded in paraffin from 32 cattle with neurological clinical signs were analyzed. These animals were submitted to necropsy at the Clínica de Bovinos de Garanhuns of the Universidade Federal Rural de Pernambuco (CBG-UFRPE), coming from 12 municipalities located in the Intermediate Region of Caruaru, Pernambuco (Fig. 1), between the years 2012 and 2016.

For DNA extraction, the ReliaPrep ${ }^{\mathrm{TM}}$ FFPE gDNA Miniprep System kit (Promega®) was used, following the manufacturer's specifications. For each animal, DNA extraction was performed with a tissue pool of 20 micrometers $(\mu \mathrm{m})$ containing four histological sections $(5 \mu \mathrm{m}$ each) of paraffinized material blocks from different parts of the central nervous system. The extracted material was frozen at $-20^{\circ} \mathrm{C}$ for further analysis.

The purity and concentration of the DNA were analyzed by using a spectrophotometer (Multiskan GO, Thermo Scientific $®$ ), and its concentration was adjusted to $100 \mathrm{ng} / \mu \mathrm{L}$. The reaction was carried out using the primers Bcon (5'-AGT GCA CGT ACA GCG GCT CG-3'. 461-480) and BoHV5 (5'-CGG ACG AGA CGC CCT TGG-3' nt. 322-339), amplifying a 159-bp product of the glycoprotein $\mathrm{C}$ gene (Claus et al., 2005). The reactions were carried out using 6.25 $\mu \mathrm{L}$ of GoTaq ${ }^{\circledR}$ Green Master Mix (Promega ${ }^{\circledR}$ ), $0.5 \mu \mathrm{L}$ of each primer in the concentration of 10 $\mu \mathrm{M}, 2.75 \mu \mathrm{l}$ of ultrapure water, and $2.5 \mu \mathrm{l}$ of DNA. The reaction was performed in a thermal cycler T100'T Thermal Cycler (Bio Rad $®)$ under the following thermal profile: initial denaturation at $95^{\circ} \mathrm{C}$ for $3 \mathrm{~min}$, followed by 40 cycles at $95^{\circ} \mathrm{C}$ $(1 \mathrm{~min}), 58^{\circ} \mathrm{C}(1 \mathrm{~min})$, and $72^{\circ} \mathrm{C}(1 \mathrm{~min})$ and a final extension for $7 \mathrm{~min}$ at $72^{\circ} \mathrm{C}$.

Recebido em 19 de agosto de 2020

Aceito em 18 de maio de 2021

E-mail: bruno_pajeu@hotmail.com 

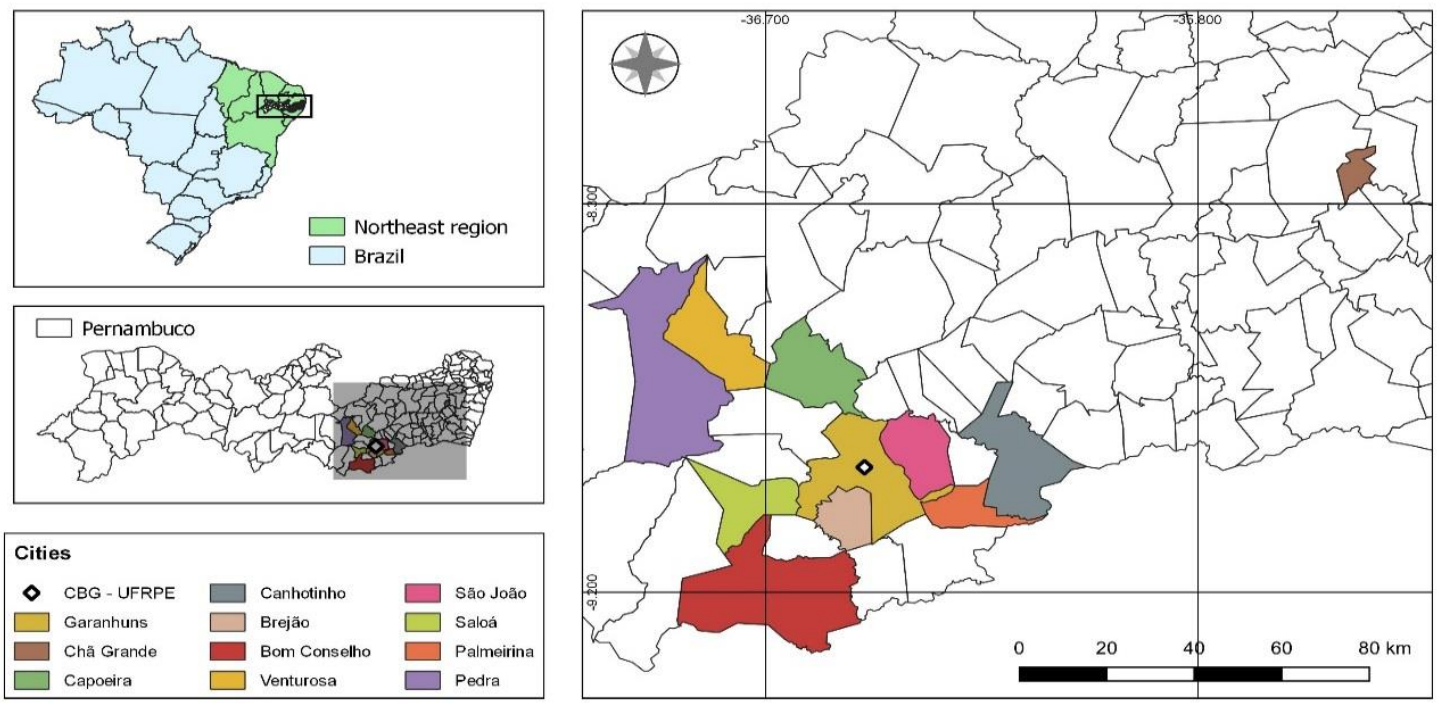

Figure 1. Municipalities of origin of the animals.

The amplified products were detected by electrophoresis on a $2 \%$ agarose gel, stained with Blue Green (LGC®), visualized through ultraviolet light, and photo documented. The positive control was obtained by DNA extraction of the reference strain BoHV5 (AA01) cultivated in Madin-Darby bovine kidney (MDBK) cell culture. For sequencing, gel bands of positive amplified products were purified using the commercial kit MEGAquick-spin ${ }^{\mathrm{TM}}$ Plus Total Fragment DNA Purification Kit (iNtRON Biotechnology $®)$. The ABI 3500 Genetic Analyzer sequencer (Applied Biosystems) was used, and the reactions were performed bidirectionally using the BigDye Terminator v3.1 Cycle Sequencing Kit (Applied Biosystems), and the conditions of polymerization were carried out in 96-well plates, according to the manufacturer's instructions. The results obtained by the sequencing were evaluated using the Staden Package 4.1.4 (Gene Codes Corporation, USA) and analyzed for similarity to sequences using the Basic Alignment Search Tools (BLAST) of the GenBank database through the National Center for Biotechnology Information (NCBI) website in order to investigate the correspondence of species identification.

Initially, a blast was made using the sequences generated in this study against the database to recover all sequences related to BoHV5. The recovered sequences were then aligned, and the evolutionary model was calculated. A Bayesian inference was made considering the calculated evolutionary model, with $5 \times 10^{7}$ generations of the Markov Monte Carlo chain (three hot and one cold chain), and the trees were sampled every 1,000 generations. Tracer (Rambaut et al., 2018) was used to view the inference results (Fig. 2).

The samples of the central nervous system embedded in paraffin were cut into sections of 5 $\mu \mathrm{m}$ and stained with hematoxylin and eosin and read in an optical microscope to describe the histopathological findings.

This research was approved by the Animal Use Ethics Committee of the Universidade Federal Rural de Pernambuco under license No. 60/2017.

In the PCR performed on the samples of the nervous system, samples 369 and 490 were positive for BoHV5, and the molecular identity was confirmed by double-stranded sequencing, which indicated a similarity of $99 \%-100 \%$ with at least 20 sequences deposited in GenBank (KY559403.1, KJ143571.1, KJ143569.1, KJ143567.1， KJ143564.1， KJ143563.1, KJ143562.1， KJ143561.1， KJ143557.1, KJ143557.1， KJ143556.1， KJ143555.1， KJ143555.1 .1， KJ143554.1， KJ143553.1, KJ143552.1， KJ143550.1， KJ143547.1, NC_005261.3, AY052396.1, KJ143551.1, among others). 


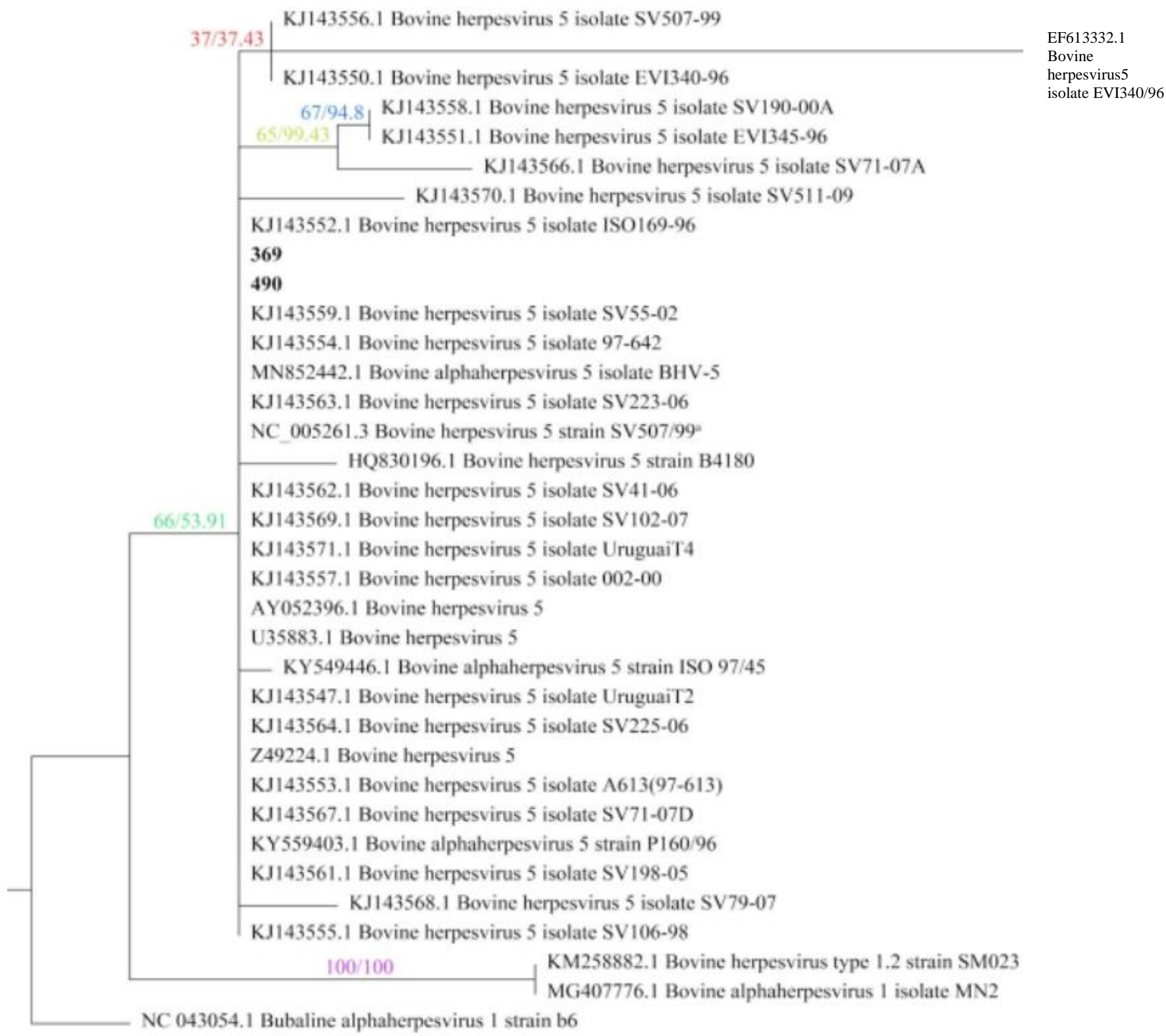

Figure 2. Phylogenetic analysis. The nucleotide sequences of the $\mathrm{gC}$ genes were edited for $157 \mathrm{bp}$ fragments, using MEGAX. These sequences, along with the nucleotide sequences representative of BoHV1 and BoHV5 available in the public domain (GenBank) were submitted for multiple sequence alignments. Phylogenetic analyzes were conducted using Garli v.2.0. Phylogenetic inference was performed using the Maximum Likelihood (ML) method and the confidence intervals were estimated by a bootstrap algorithm applying 1,000 iterations, divided into 4 runs of 250 each. The tree is drawn to scale, with the lengths of the branches in the same units as the evolutionary distances used to infer the phylogenetic tree. Bootstrap values are shown on each branch followed by Bayesian inference (IB) values, eg. ML / IB. 
Sequences of two isolates, 369 and 490, belonging to the $\mathrm{gC}$ gene (Glycoprotein $\mathrm{C}$ ) were assembled using the Staden package, generating sequences of 154 and $157 \mathrm{bp}$, respectively. After the blast, 30 BoHV5 sequences were recovered from the bank and two Bubaline alphaherpesvirus 1 and one Bovine alphaherpesvirus 1 sequence were added to the analyzes. The evolutionary model calculated was HKY $+\mathrm{F}$ according to the Bayesian information criterion (BIC).

The phylogenetic tree built (Fig. 2), both for the likelihood method and for Bayesian, presented similar topologies, but with support values that are not very similar. The isolates sequenced in the present study were grouped with BoHV5 isolates with $100 \%$ bootstrap/probability suggesting that the virus is closely related to BoHV5 isolates.

Bovine alphaherpesvirus 5 is an important cattle pathogen, with high prevalence in South America (Perez et al., 2002). However, despite its importance and the critical role of $\mathrm{gC}$ in viral biology and its implications for diagnosis, limited information is available on the $\mathrm{gC}$ of both viruses (BoHV1 / BoHV5). Available on GenBank, about 30 sequences of BoHV-5 were found via blast, including sequences taken from the genome, covering $157 \mathrm{bp}$, of those sequenced in the present study. The results are similar to those found in previous studies (Maidana et al., 2011; Traesel et al., 2015). However, specific studies are still lacking regarding the determination of strains for the studied gene $(\mathrm{gC})$.

As the samples were preserved in $20 \%$ formalin solution, it is possible that the results presented may be underestimated because there are limitations to the technique for detecting genetic material in paraffinized samples, given that the nucleic acid undergoes denaturation when fixed for a long period or when the formaldehyde is not buffered (Crawford et al., 1999). Arruda et al. (2010) observed a greater positivity for BoHV1 and BoHV5 in samples preserved in $10 \%$ formalin solution for less than 40 days. Meanwhile, the samples preserved for a longer period showed a lower positivity.

The clinical history of animals positive for BoHV5 consisted of apathy, sialorrhea, inappetence, head tremors, low head, ataxia, reduced visual acuity, bilateral nasal discharge, and oligopneic breathing associated with expiratory dyspnea. The clinical course of the affected animals was 6 days, showing the high lethality of the involved agent, which is in accordance with the findings described by Aquino Neto et al. (2009). The variation of signs depends on factors such as the presence of concomitant diseases, including polioencephalomalacia (David, 2002), which markedly accentuate the lesions of meningoencephalitis, and the immune status of the animals (Belknap et al., 1994) proved by the action of passive immunity in the protection of animals exposed to the virus, and the viral sample.

Histopathological findings consisted of non-suppurative, multifocal, moderate, chronic meningoencephalitis associated with polioencephalomalacia. These findings corroborate the studies by Galiza et al. (2010), who also identified this type of injury in the affected animals. One of the animals that presented with lesions was diagnosed with polioencephalomalacia, showing a marked malacia lesion. David (2002) suggested that the clinical cases of reactivation of latent BoHV5 infections, as well as the severity of the cases, are associated with the previous development of polioencephalomalacia. In his studies (David, 2002), animals that developed both polioencephalomalacia and meningoencephalitis due to BoHV5 showed more pronounced malacia lesions.

As demonstrated in the study by Pedraza and Alessi (2010), in which 33.3\% (5/15) positivity for BoHV5 was detected in samples of paraffin material diagnosed with meningoencephalitis, PCR is an important tool not only for the diagnosis of ongoing cases, but also for its use in retrospective studies on the occurrence of neurological diseases from a sample bank.

One of the animals that were positive by PCR for BoHV5 was diagnosed with polioencephalomalacia. The other animal, which was also confirmed as positive for BoHV5, had clinical suspicion of rabies in its medical records, which shows the importance of this tool, PCR, in the diagnosis of BoHV5 infection.

Several studies have described that among the neurological disorders of cattle, non-suppurative meningoencephalitis is the main histological finding caused by infectious diseases (Galiza et 
al., 2010; Queiroz et al., 2018; Terra et al., 2018). A study carried out in Paraíba state, Brazil, describes this lesion associated with malacia (Galiza et al., 2010).

Although the characteristic lesion of nonsuppurative meningoencephalitis is attributed to BoHV5, the same lesion can also be present in some cases of infection by BoHV1 due to its tropism by the central nervous system, as well as cases of rabies and malignant bluetongue (Barros et al., 2006). Therefore, it is necessary to confirm the infection by diagnostic techniques that allow the distinction between types 1 and 5 of bovine alphaherpes virus.

Confirmation by PCR of the BoHV5 occurrence among cases of neurological diseases in cattle shows the importance of molecular tests for definitive diagnosis, mainly for suspected cases of
The distribution of diseases of neurological origin can vary due to regional particularities. For this reason, it is necessary to identify the agents of regional circulation such that appropriate strategies can be conducted to minimize losses (Queiroz et al., 2018). In addition, the low frequency of disease reports caused by BoHV5 is related to the difficulty in identifying the cause due to the similarity of the clinical signs and the difficulty in performing differential diagnoses. This is due to the multiple signs or lack of technical structure in the laboratories (Aquino Neto et al., 2009) added to the lack of knowledge of BoHV5 occurrence in the region or the particularities associated with the infection by the agent.

rabies, an endemic disease of cattle in the Brazilian Northeast region.

Keywords: PCR, paraffinized samples, neurological disease, BoHV5, SNC

\section{RESUMO}

Objetivou-se descrever a ocorrência do Bovine alphaherpesvirus 5 (BoHV5) como causa de meningoencefalite não supurativa em bovinos do estado de Pernambuco, Brasil. Para tanto, 32 amostras de sistema nervoso embebidas em parafina foram obtidas de animais acometidos por doenças neurológicas atendidos na Clínica de Bovinos de Garanhuns da Universidade Federal Rural de Pernambuco (CBGUFRPE), entre 2012 e 2016. As amostras foram analisadas quanto à presença do gene da glicoproteína $C$ do BoHV5 por reação em cadeia da polimerase (PCR). Dois animais $(6,25 \%)$ tiveram resultado positivo à PCR, e sua análise de sequenciamento indicou 100\% de similaridade para o BoHV5. Os resultados histopatológicos desses dois animais revelaram lesões multifocais de meningoencefalite não supurativa associada à polioencefalomalácia, presença de corpúsculos de inclusão basofílicos, infiltração de células de Gitter e presença de manguitos perivasculares. A PCR se mostra uma importante ferramenta para diferenciação das infecções por BoHV5 de outras enfermidades neurológicas de bovinos, especialmente a raiva.

Palavras-chave: PCR, amostras em parafina, doença neurológica, BoHV5, SNC

\section{REFERENCES}

AQUINO NETO, H.M.; CARVALHO, A.U.; FACURY FILHO, E.J. et al. Meningoencefalite por Herpesvirus bovino 5 em Minas Gerais: relato de caso clínico. Arq. Bras. Med. Vet. Zootec., v.61, p.1-5, 2009.

ARRUDA, L.P.; NAKAZATO, L.; DUTRA, V. et al. Detecção molecular de herpesvírus bovino 1 e 5 em amostras de encéfalo conservadas em formol e emblocadas em parafina provenientes de bovinos com doença neurológica. Pesqui. Vet. Bras., v.30, p.646-650, 2010.

BARROS, C.L.S.; DRIEMEIER, D.; DUTRA, I.S.; LEMOS, R.A.A. Doenças do sistema nervoso de bovinos no Brasil. Montes Claros, MG: Vallée, 2006. 207p.

BELKNAP, E.B.; COLLINS, J.K.; AYERS, V.K.; SCHULTHEISS, P.C. Experimental infection of neonatal calves with neurovirulent bovine herpesvirus type 1.3. Vet. Pathol., v.31, p.358-365, 1994. 
CLAUS, M.P.; ALFIERI, A.F.; FOLGUERASFLATSCHART, A.V. et al. Rapid detection and differentiation of bovine herpesvirus 1 and 5 glycoprotein $\mathrm{C}$ in clinical specimens by multiplex-PCR. J. Virol. Methodol., v.128, p.183188, 2005.

CRAWFORD, T.B.; LI, H.; O'TOOLE, D. Diagnosis of malignant catarral fever by PCR using formalin-fixed, paraffin-embedded tissues. J. Vet. Diagn. Invest., v.11, p.111-116, 1999.

DAVID, N. Associação de meningoencefalite por herpesvírus bovino-5 com polioencefalomalacia. 2002. 55f. Dissertação (Programa de PósGraduação em Veterinária) - Faculdade de Veterinária, Universidade Federal de Pelotas, Pelotas, RS.

GALIZA, G.J.N.; SILVA, M.L.C.R.; DANTAS, A.F.M. et al. Doenças do sistema nervoso de bovinos no semiárido nordestino. Pesqui. Vet. Bras., v.30, p.267-276, 2010.

MAIDANA, S.S.; LADELFA, M.F.; PÉREZ, S.E. et al. Characterization of BoHV-5 field strains circulation and report of transient specific subtype of bovine herpesvirus 5 in Argentina. BMC Vet. Res., v.7, 8p, 2011.

PEDRAZA, F.J.; ALESSI, A.C. Detection of bovine herpesvirus 5 (BoHV-5) in formalin-fixed, paraffin-embedded bovine brain by nested PCR in Colombian cattle. Rev. Colomb. Cienc. Pecu., v.23, p.292-298, 2010.
PEREZ, S.E.; BRETSCHNEIDER, G.; LEUNDA, M.R. et al. Primary infection, latency, and reactivation of bovine herpesvirus type 5 in the bovine nervous system. Vet. Pathol., v.39, p.437-444, 2002.

QUEIROZ, G.R.; OLIVEIRA, R.A.M.; FLAIBAM, K.M.C. et al. Diagnóstico diferencial das doenças neurológicas dos bovinos no estado do Paraná. Pesqui. Vet. Bras., v.38, p.1264-1277, 2018.

RAMBAUT, A.; DRUMMOND, A.J.; XIE, D.; BAELE, G.; SUCHARD, M.A. Posterior summarization in Bayesian phylogenetics using Tracer 1.7. Syst Biol., v.67, p.901-904, 2018.

RISSI, D.R.; OLIVEIRA, F.N.; RECH, R.R. et al. Epidemiologia, sinais clínicos e distribuição das lesões encefálicas em bovinos afetados por meningoencefalite por herpesvírus bovino-5. Pesqui. Vet. Bras., v.26, p.123-132, 2006.

TERRA, J.P.; BLUME, G.R.; RABELO, R.E. et al. Neurological diseases of cattle in the state of Goiás, Brazil (2010-2017). Pesqui. Vet. Bras., v.38, p.1752-1760, 2018.

TRAESEL, C.K.; BERNARDES, L.M.; SPILKI, F.R. et al. Sequence analysis of the 5' third of glycoprotein $\mathrm{C}$ gene of South American bovine herpesviruses 1 and 5. Braz. J. Med. Biol. Res., v.48, p.470-478, 2015. 